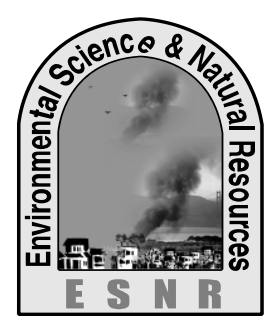

\title{
Profiling of Physical and Chemical Properties of Mango at Different Ripening Stages
}

\author{
M. S. Islam ${ }^{1}$, M. G. Aziz ${ }^{2}$, M. G. Mortuza ${ }^{3}$ and M. A. Rahman ${ }^{\text {* }}$ \\ ${ }^{1}$ Department of Horticulture, ${ }^{2}$ Department of Food Technology and Rural Industries, \\ ${ }^{3}$ Department of Biochemistry and Molecular Biology, \\ Bangladesh Agricultural University, Mymensingh-2202 \\ *Corresponding author: arahman@bau.edu.bd
}

\begin{abstract}
The experiments were carried out to assess the quality of mango at different ripening stages. The two factor experiment was laid out in completely randomized design (CRD) with three replications. The experiment comprised four varieties, viz., $\mathrm{V}_{1}$ : BAU Aam-1, $\mathrm{V}_{2}$ : BAU Aam-6, $\mathrm{V}_{3}$ : BAU Aam-7, $\mathrm{V}_{4}$ : BAU Aam-8 and five ripening stages. Among the attributes total weight loss, dry matter content, total soluble solids (TSS), sugar content (total, reducing and non-reducing), disease incidence increased, while the moisture, vitamin C contents and titratable acidity decreased with the increase in duration of storage. Among the four varieties, BAU Aam-6 showed better results in relation to the most of the characters examined. Ripening stage- 5 of mango fruit was observed to be the best among the five ripening stages in relation to the most of the chemical characters examined. Finally, it can be concluded that the results of this experiment will be useful with particular reference to quality control, preparation for transportation and marketing, and will also be beneficial for both the growers and consumers.
\end{abstract}

Key words: Chemical property, Mango, Physical property and Ripening stage

\section{Introduction}

Mango (Mangifera indica L.) is a popular and fleshy fruit belonging to the genus Mangifera, under the botanical family Anacardiaceace. Mango is recognized one of the best fruits of all indigenous fruits due to its excellent flavor, attractive fragrance and beautiful shades of color, delicious taste and high nutritive value. It is grown commercially in seven countries. Several hundred varieties are grown in the Indian subcontinent but a few specific varieties are commercialized according to preference of different regions of the countries. About 250 varieties are grown in Bangladesh (Shafique, 2006).

Mango is grown in tropical and sub tropical climates. Due to soil and climatic limitations production of quality mangoes is confined only to the North-West region of the country such as Chapai Nawabgonj, Rajshahi, Rangpur, Dinajpur, Kushtia and Jessore. In Bangladesh in terms of total area and production of fruit crops, mango ranks second in terms of area and production. During the period of 2010-2011 it occupies 27466.40 hectare of land total production was 889176 metric tons (BBS, 2012). But the yield is very low compared to that of India, Pakistan and other countries of the world (Hossain and Ahmed, 1994).

The mango is nutritionally superior and one of the most valuable fruits in the world. It is rich in several vitamins. It is a source of vitamins (especially $\beta$ carotene and $\mathrm{C}$ ), minerals and total soluble solids (Pramanik, 1995). Ripe mango contains a high amount of carotene. It is also a medium source of carbohydrates (Salunkhe and Desai, 1984). In addition, each $100 \mathrm{~g}$ edible portion of mango as much as $74 \mathrm{Kcal}$ which is nearly equals the energy values of boiled rice of similar quantity by weight (Hossain, 1989a). Consumer acceptance is mostly dependent on color of the product (Crisosto et al., 2003). Its starch is used in confectionery industry. Mango has also medicinal uses. The ripe fruit has fattening, diuretic and laxative properties. It helps to increase digestive capacity.
Mango is a climacteric fruit, so the physical and chemical properties of mango change with different stage of ripening during storage. It is necessary to study the changes of physical and chemical properties of mango at different ripening stage. However, due to lack of scientific information on physiochemical characters of the fruit of mango grown under Bangladesh conditions, a large quantity of this valuable fruit is wasted during the peak season, particularly in "on" years. With this end in view, the present study was, therefore, carried out to see the physical and chemical changes at different ripening stage during storage.

\section{Materials and Methods}

The experiment was conducted at the Laboratory of the Department of Horticulture, and Department of Biochemistry and Molecular Biology, Bangladesh Agricultural University (BAU), Mymensingh, during the period from July to August, 2015.

The experimental materials were mature hard fruits of four mango varieties, namely, cvs. BAU Aam-1, BAU Aam-6, BAU Aam-7 and BAU Aam-8, which were collected from BAU-GPC (Germplasm Centre). Maturity of mangoes was indicated when the shoulders were in line with the stem end and the color was olive green. Maturity was also judged by the grower's recommendation with uniform size, shape, and free of any visible defects, disease symptoms and insect infestations were harvested. Then mangos were transported to the post-graduate Laboratory of the Department of Horticulture, BAU, Mymensingh. It was done carefully to avoid damage and injury. The skin adherences, dots and latex were cleaned by gently wiping the fruits with moist and clean towel.

The two factor experiment was laid out in completely randomized design (CRD) with three replications. The experiment comprised four varieties, viz., $\mathrm{V}_{1}$ : BAU Aam-1, $\mathrm{V}_{2}$ : BAU Aam-6, $\mathrm{V}_{3}$ : BAU Aam-7, $\mathrm{V}_{4}$ : BAU Aam- 8 and five ripening stages, viz., stage-1 (unripe): 
when mango at light green color, stage-2 (early ripe): when mango turns from a lighter green to yellow color, stage-3 (partially ripe): when mango represents a halfgreen half-yellow color, stage-4 (ripe): when mango turns more yellow/orange and begins to soften, stage-5 (over ripe): when mango shows a golden yellow color.

\section{Parameter studies}

Physical parameters, such as, total weight loss, Moisture content, Dry matter content and Chemical parameters, such as, Total soluble solids (TSS), Vitamin C, Titratable Acidity (TA), Reducing sugar, Nonreducing sugar, Total sugar were studied in the present experiment.

\section{Method of studying parameters}

Weight loss, moisture - , dry matter -, total soluble solids- , reducing-, non-reducing and total sugarcontent were determined according to AOAC (2000). Ascorbic acid content and titratable acidity were determined according to the method of Ranganna (1979).

\section{Results and Discussion}

Table 1. Effect of varieties on physical characters of mango during ripening

\begin{tabular}{|c|c|c|c|}
\hline Variety & Weight loss $(\%)$ & Moisture content $(\%)$ & Dry matter content $(\%)$ \\
\hline BAU Aam-1 $\left(\mathrm{V}_{1}\right)$ & 4.80 & 82.95 & 17.05 \\
\hline BAU Aam-6 $\left(\mathrm{V}_{2}\right)$ & 5.13 & 81.87 & 18.13 \\
\hline BAU Aam-7 $\left(\mathrm{V}_{3}\right)$ & 6.30 & 81.90 & 19.10 \\
\hline BAU Aam-8 $\left(\mathrm{V}_{4}\right)$ & 5.98 & 80.19 & 0.256 \\
\hline LSD $_{0.05}$ & 0.148 & 0.424 & 0.342 \\
\hline LSD $_{0.01}$ & 0.197 & 0.567 & $* *$ \\
\hline$*$ Significant at 1\% level of probability & $* *$ & $* *$ & \\
\hline
\end{tabular}

Percent total soluble solids (TSS) contents increasing with the increase of storage period for all four varieties. The highest total soluble solids contents (19.73\% Brix) was found in cv. BAU Aam-8 and the lowest total soluble solids content (18.39\% Brix) was found in BAU Aam-1 during storage whereas (Table 4). This increase in TSS content is due to the conversion of complex carbohydrates into simple sugars. This is correlated with hydrolytic changes in starch and conversion of starch to sugar being an important index of ripening process in mango and other climacteric fruits and further hydrolysis decreased the TSS contents during storage (Kays, 1991; Kittur et al., 2001). The highest vitamin $\mathrm{C}$ content was recorded in cv. BAU Aam-6 (53.91 mg $100 \mathrm{~g}^{-1}$ ) and lowest (22.62 mg $100 \mathrm{~g}^{-1}$ ) in BAU Aam-1 (Table 4). It was also remarkable that vitamin $\mathrm{C}$ contents declined steadily up to the end of ripening stage during storage. Absar et al. 1993 supported the above results of vitamin C. It was observed that BAU Aam- 8 had highest titratable acidity $(2.38 \%)$ and lowest (1.88\%) in BAU Aam-6 (Table 4). Titratable acidity was decreased gradually with the
The results of the present study on changes in various physico-chemical parameters during storage and ripening of four varieties of mango are discussed in this chapter. Effects of variety and ripening stages on postharvest storage behavior namely weight loss, moisture content, dry matter content, total soluble solids, vitamin $\mathrm{C}$, titratable acidity, total sugar contents, reducing sugar contents, non-reducing sugar contents, disease incidence, disease severity, causal pathogens as observed during the study have been discussed in the following sub-heading.

\section{Effect of variety on quality of mango during storage}

The highest weight loss $(6.30 \%)$ was recorded in cv. BAU Aam-7 followed by BAU Aam-8 (5.98\%), BAU Aam-6 $(5.13 \%)$ while the lowest $(4.80 \%)$ in BAU Aam1 during storage (Table 1). The highest moisture content was recorded during storage in cv. BAU Aam-1 $(82.95 \%)$ followed by BAU Aam-7 (81.90\%), BAU Aam-6 (81.87\%) while the lowest $(80.19 \%)$ in BAU Aam-8 (Table 1). Among the four varieties highest dry matter content was recorded in cv. BAU Aam-8 $(19.81 \%)$ while lowest $(17.05 \%)$ in BAU Aam-1 (Table $1)$. progresses of storage time. Total sugar content was observed higher $(13.82 \%)$ in cv. BAU Aam-6 and lower total sugar content $(12.33 \%)$ was observed in cv. BAU Aam-7 (Table 4). However, the total sugar content was increasing trend in all four varieties during storage. Firmin, 1997 found increased reducing sugar content during maturation of the local and solo variety of papaya. Beside decrease the sugar content with the increasing storage period. Reducing sugar content was observed higher (6.96\%) in cv. BAU Aam-6 and lower reducing sugar content $(6.29 \%)$ was observed in $\mathrm{cv}$. BAU Aam-7 (Table 4). However, the reducing sugar content was increasing trend during storage. Nonreducing sugar content was observed higher $(6.86 \%)$ in cv. BAU Aam-6 at and lower non-reducing sugar content $(6.04 \%)$ was observed in cv. BAU Aam-7 (Table 4). However, the non-reducing sugar content was increasing trend in both cases during storage.

The highest $(31.47 \%)$ disease incidence observed in $\mathrm{cv}$. BAU Aam-1, but cv. BAU Aam-6 showed the lowest (18.53\%) disease incidence and BAU Aam-7 (22.20\%) 
and BAU Aam-8 showed (25.93\%) disease incidence

(data not shown in table).

Table 2. Effect of ripening stages on physical characters of mango during ripening

\begin{tabular}{|l|c|c|c|}
\hline Ripening stage & Weight loss (\%) & Moisture content (\%) & Dry matter content (\%) \\
\hline $\mathrm{S}_{1}$ & - & 84.25 & 15.75 \\
\hline $\mathrm{S}_{2}$ & 3.35 & 82.88 & 17.12 \\
\hline $\mathrm{S}_{3}$ & 7.13 & 81.77 & 18.23 \\
\hline $\mathrm{S}_{4}$ & 6.83 & 81.04 & 21.29 \\
\hline $\mathrm{S}_{5}$ & 4.90 & 78.71 & 0.258 \\
\hline LSD $_{0.05}$ & 0.149 & 0.428 & 0.348 \\
\hline LSD $_{0.01}$ & 0.201 & 0.577 & $* *$ \\
\hline Level of significance & $* *$ & $* *$ & \\
\hline
\end{tabular}

$S_{1}$ (Unripe) = When mango at light green color, $S_{2}$ (Early ripe) = When mango turns from a lighter green to yellow, $S_{3}$ (Partially ripe) $=$ When mango represents a half-green half-yellow color, $\mathrm{S}_{4}$ (Ripe) $=$ When mango turns more yellow/orange and begins to soften, $\mathrm{S}_{5}$ (Over ripe) $=$ When mango shows a golden yellow color $(* *$ Significant at $1 \%$ level of probability).

\section{Effect of ripening stages on quality of mango during storage}

The highest total weight loss $(7.13 \%)$ was found at ripening stag-3 followed by ripening stage-5 (4.90\%), ripening stage-4 $(6.83 \%)$ while the lowest total weight loss $(3.35 \%)$ was at ripening stage-2 (Table 2). Haque (1985) reported that the weight loss of bananas occurred due to the loss of water from the fruits, microbial decay and storage environment like temperature and humidity. High temperature enhanced weight loss but low temperature reduced weight loss during ripening and storage. Treated fruits showed lower weight loss than untreated fruits which is similar as report of Naher (2000). Naher noted that refrigerated $(9.73 \%)$ and perforated polythene bagged $(11.74 \%)$ fruits showed minimum total weight loss during storage, whereas untreated fruits exhibited maximum $(22.90 \%)$ weight loss. Highest rate of moisture content $(84.25 \%)$ was found at ripening stage-1 and lowest $(78.71 \%)$ at ripening stage-5 (Table 2). At ripening stage-5 highest rate $(21.29 \%)$ of dry matter content was recorded and lowest $(15.75 \%)$ at ripening stage-1 (Table 2).

Table 3. Combined effects of varieties and ripening stages on physical characters of mango during ripening

\begin{tabular}{|c|c|c|c|c|}
\hline Variety & Ripening stages & $\begin{array}{c}\text { Weight loss } \\
(\%)\end{array}$ & $\begin{array}{c}\text { Moisture content } \\
(\%)\end{array}$ & $\begin{array}{c}\text { Dry matter content } \\
(\%)\end{array}$ \\
\hline \multirow{5}{*}{ BAU Aam-1 $\left(\mathrm{V}_{1}\right)$} & $\mathrm{S}_{1}$ & 0 & 84.53 & 15.47 \\
\hline & $\mathrm{S}_{2}$ & 2.30 & 84.59 & 15.41 \\
\hline & $\mathrm{S}_{3}$ & 6.40 & 83.50 & 16.50 \\
\hline & $\mathrm{S}_{4}$ & 7.30 & 82.86 & 17.14 \\
\hline & $\mathrm{S}_{5}$ & 3.20 & 79.29 & 20.71 \\
\hline \multirow{5}{*}{ BAU Aam-6 $\left(\mathrm{V}_{2}\right)$} & $\mathrm{S}_{1}$ & 0 & 84.61 & 15.39 \\
\hline & $\mathrm{S}_{2}$ & 2.80 & 82.42 & 17.58 \\
\hline & $\mathrm{S}_{3}$ & 5.60 & 81.55 & 18.45 \\
\hline & $\mathrm{S}_{4}$ & 7.50 & 80.77 & 19.23 \\
\hline & $\mathrm{S}_{5}$ & 4.60 & 79.98 & 20.02 \\
\hline \multirow{5}{*}{ BAU Aam-7 $\left(V_{3}\right)$} & $\mathrm{S}_{1}$ & 0 & 85.24 & 14.76 \\
\hline & $\mathrm{S}_{2}$ & 4.70 & 83.07 & 16.93 \\
\hline & $\mathrm{S}_{3}$ & 10.20 & 81.79 & 18.21 \\
\hline & $\mathrm{S}_{4}$ & 4.90 & 81.10 & 18.90 \\
\hline & $\mathrm{S}_{5}$ & 5.40 & 78.30 & 21.70 \\
\hline \multirow{5}{*}{ BAU Aam-8 $\left(\mathrm{V}_{4}\right)$} & $\mathrm{S}_{1}$ & 0 & 82.60 & 17.40 \\
\hline & $\mathrm{S}_{2}$ & 3.60 & 81.44 & 18.56 \\
\hline & $\mathrm{S}_{3}$ & 6.30 & 80.23 & 19.77 \\
\hline & $\mathrm{S}_{4}$ & 7.60 & 79.42 & 20.58 \\
\hline & $\mathrm{S}_{5}$ & 6.40 & 77.26 & 22.74 \\
\hline $\mathrm{LSD}_{0.05}$ & & 0.298 & 0.857 & 0.517 \\
\hline $\mathrm{LSD}_{0.01}$ & & 0.402 & 1.154 & 0.696 \\
\hline Level of significance & & $* *$ & $* *$ & $* *$ \\
\hline
\end{tabular}


The highest value of TSS (22.13\% Brix) was observed at ripening stage-5 where lowest value of TSS $(12.96 \%$ Brix) was observed at ripening stage-1 (Table 5). The highest vitamin $\mathrm{C}$ content $\left(54.05 \mathrm{mg} 100 \mathrm{~g}^{-1}\right)$ was recorded at ripening stage- 1 and lowest $(19.77 \mathrm{mg} 100$ $\mathrm{g}^{-1}$ ) at ripening stage-5 (Table 5). It was also remarkable that vitamin $\mathrm{C}$ contents declined steadily up to the end of ripening stage during storage. Highest titratable acidity $(3.59 \%)$ was recorded at ripening stage- 1 and lowest $(1.22 \%)$ at ripening stage-5 (Table 5). Titratable acidity was decreased gradually with the progresses of ripening stage. At ripening stage-5, the highest total sugar content $(17.14 \%)$ was recorded while the lowest total sugar content $(6.88 \%)$ was found at ripening stage1 (Table 5).

The postharvest storage treatments used in the present study showed a noticeable effect on reducing sugar content of mango during storage. The highest rate of reducing sugar content $(8.96 \%)$ was recorded at ripening stage-5 while lowest rate reducing sugar content $(4.03 \%)$ was found at ripening stage-1 (Table 5). Further, it was noticed that the reducing sugar content was gradually increasing in all the ripening stages, during storage. At ripening stage-5, the highest non-reducing sugar content $(8.18 \%)$ was observed while the lowest non-reducing sugar content $(2.85 \%)$ was found at ripening stage-1 (Table 5).

Table 4. Effect of varieties on chemical characteristics of mango during ripening

\begin{tabular}{|l|c|c|c|c|c|c|}
\hline Variety & $\begin{array}{c}\text { TS content } \\
(\%)\end{array}$ & $\begin{array}{c}\text { RS content } \\
(\%)\end{array}$ & $\begin{array}{l}\text { NRS content } \\
(\%)\end{array}$ & $\begin{array}{c}\text { TSS } \\
(\% \text { Brix })\end{array}$ & $\begin{array}{c}\text { Vitamin C } \\
\text { content }(\mathrm{mg} \%)\end{array}$ & TA (\%) \\
\hline BAU Aam-1 $\left(\mathrm{V}_{1}\right)$ & 12.49 & 6.35 & 6.14 & 18.39 & 22.62 & 2.27 \\
\hline BAU Aam-6 $\left(\mathrm{V}_{2}\right)$ & 13.82 & 6.96 & 6.86 & 19.07 & 53.91 & 1.88 \\
\hline BAU Aam-7 $\left(\mathrm{V}_{3}\right)$ & 12.33 & 6.29 & 6.04 & 18.41 & 39.95 & 1.90 \\
\hline BAU Aam-8 $\left(\mathrm{V}_{4}\right)$ & 13.37 & 6.86 & 6.51 & 19.73 & 41.22 & 2.38 \\
\hline LSD $_{0.05}$ & 0.285 & 0.052 & 0.179 & 0.266 & 0.782 & 0.058 \\
\hline LSD $_{0.01}$ & 0.381 & 0.070 & 0.239 & 0.356 & 1.046 & 0.078 \\
\hline $\begin{array}{l}\text { Level of } \\
\text { significance }\end{array}$ & $* *$ & $* *$ & $* *$ & $* *$ & $* *$ & $* *$ \\
\hline
\end{tabular}

$\mathrm{TS}=$ Total sugar; $\mathrm{RS}=$ Reducing sugar NRS= Non-reducing sugar; $\mathrm{TSS}=$ Total soluble solids; $\mathrm{TA}=$ Titratable acidity ** Significant at $1 \%$ level of probability

\section{Combined effects of variety and ripening stages on quality of mango during storage}

The combined effect of ripening stages and varieties on total weight loss was highly significant in all stages that observed. The highest total weight loss $(10.20 \%)$ was found in BAU Aam-7 at ripening stage-3, while it was the lowest $(2.30 \%)$ in BAU Aam-1 at ripening stage-2 (Table 3). Highest rate of moisture content (85.24\%) was found at ripening stage-1 in BAU Aam-7 and lowest $(77.26 \%$ ) at ripening stage-5 in BAU Aam-8 (Table 3). Dry matter content was in the increasing trend at varying degrees as influenced by different ripening stages. The amount of dry matter content was higher in BAU Aam-8 at ripening stage-5 than those of other ripening stages. The highest dry matter content $(22.74 \%)$ was found in BAU Aam-8 at ripening stage-5 and the lowest dry matter content $(14.76 \%)$ was observed in BAU Aam-7 at ripening stage-1 (Table 3).

Table 5. Effect of ripening stages on chemical characteristics of mango during ripening

\begin{tabular}{|l|c|c|c|c|c|c|}
\hline $\begin{array}{l}\text { Ripening } \\
\text { stage }\end{array}$ & $\begin{array}{l}\text { TS content } \\
(\%)\end{array}$ & $\begin{array}{l}\text { RS content } \\
(\%)\end{array}$ & $\begin{array}{l}\text { NRS content } \\
(\%)\end{array}$ & $\begin{array}{l}\text { TSS } \\
(\% \text { Brix })\end{array}$ & $\begin{array}{l}\text { Vitamin C } \\
\text { content }(\mathrm{mg} \%)\end{array}$ & $\begin{array}{l}\text { TA } \\
(\%)\end{array}$ \\
\hline $\mathrm{S}_{1}$ & 6.88 & 4.03 & 2.85 & 12.96 & 54.05 & 3.59 \\
\hline $\mathrm{S}_{2}$ & 11.45 & 4.78 & 6.67 & 18.58 & 44.62 & 2.39 \\
\hline $\mathrm{S}_{3}$ & 14.21 & 7.12 & 7.09 & 19.55 & 42.06 & 1.91 \\
\hline $\mathrm{S}_{4}$ & 15.34 & 8.19 & 7.15 & 21.29 & 36.64 & 1.44 \\
\hline $\mathrm{S}_{5}$ & 17.14 & 8.96 & 8.18 & 22.13 & 19.77 & 1.22 \\
\hline $\mathrm{LSD}_{0.05}$ & 0.288 & 0.053 & 0.181 & 0.269 & 0.790 & 0.059 \\
\hline LSD $_{0.01}$ & 0.387 & 0.071 & 0.243 & 0.362 & 1.064 & 0.079 \\
\hline $\begin{array}{l}\text { Level of } \\
\text { significance }\end{array}$ & $* *$ & $* *$ & $* *$ & $* *$ & $* *$ & $* *$ \\
\hline
\end{tabular}


The combined effects of variety and ripening stages of mango in respect of TSS content was significant during storage period. The degree of increase in TSS value for different ripening stages might be due to the modified internal atmosphere and physiological aspects of mango fruits, suppressed respiration and metabolic processes, which involve in increasing TSS at different magnitudes. The highest TSS content $(22.95 \%$ Brix $)$ was found in BAU Aam- 6 at ripening stage-5, while the lowest TSS content (12.25\% Brix) was found in BAU Aam-1 at ripening stage-1 (Table 6). This increase in TSS content is due to the conversion of complex carbohydrates into simple sugars. This is correlated with hydrolytic changes in starch and conversion of starch to sugar being an important index of ripening process in mango and other climacteric fruits and further hydrolysis decreased the TSS content during storage (Kays, 1991; Kittur et al., 2001). The combined effects of variety and ripening stages on vitamin $\mathrm{C}$ content were significant during storage period. The lower vitamin C content (18.15 mg $\left.100 \mathrm{~g}^{-1}\right)$ was observed in BAU Aam-1 at ripening stage-5 and the higher vitamin $\mathrm{C}$ content $\left(72.50 \mathrm{mg} 100 \mathrm{~g}^{-1}\right)$ was found in BAU Aam-6 at ripening stage-1 (Table 6). This result is supported with the findings of Shahjahan et al. (1994). They stated that maximum portion vitamin C was lost when the fruits were stored at room temperature $\left(26-30^{\circ} \mathrm{C}\right)$. The combined effects of variety and different ripening stages in respect of titratable acidity were statistically significant during storage period. The higher titratable acidity (4.04\%) was recorded in BAU Aam- 8 at ripening stage- 1 and the lowest $(1.18 \%)$ was found in BAU Aam-1 at ripening stage-5 (Table 6). The highest total sugar content (18.50\%) was observed in cv. BAU Aam-6 at ripening stage-5 while the lowest $(6.42 \%)$ in cv. BAU Aam-1 at ripening stage-1 (Table 6). Considering the combined effects, the highest reducing sugar content (9.49\%) observed in cv. BAU Aam-6 at ripening stage-5, while the lowest $(3.85 \%)$ observed in cv. BAU Aam-1 at ripening stage-1 (Table 6). The highest non-reducing sugar content $(9.01 \%)$ in $\mathrm{cv}$. BAU Aam-6 at ripening stage-5, while the lowest $(2.57 \%)$ in cv.BAU Aam-1 at ripening stage-1 (Table 6). Initial rise in non-reducing sugar content may be due to the breakdown of starch into non-reducing sugar and subsequent slower increase may be attributed to conversion of some of nonreducing sugars to reducing sugar.

Table 6. Combined effects of varieties and ripening stages on chemical characteristics of mango during ripening

\begin{tabular}{|c|c|c|c|c|c|c|c|}
\hline Variety & $\begin{array}{l}\text { Ripening } \\
\text { stages }\end{array}$ & $\begin{array}{l}\text { TS content } \\
(\%)\end{array}$ & $\begin{array}{l}\text { RS content } \\
(\%)\end{array}$ & $\begin{array}{l}\text { NRS content } \\
(\%)\end{array}$ & $\begin{array}{l}\text { TSS } \\
(\% \text { Brix })\end{array}$ & $\begin{array}{l}\text { Vitamin } \mathrm{C} \\
\text { content }(\mathrm{mg} \%)\end{array}$ & TA $(\%)$ \\
\hline \multirow{5}{*}{$\begin{array}{l}\text { BAU Aam-1 } \\
\left(\mathrm{V}_{1}\right)\end{array}$} & $\mathrm{S}_{1}$ & 6.42 & 3.85 & 2.57 & 12.25 & 32.20 & 3.64 \\
\hline & $\mathrm{S}_{2}$ & 11.13 & 4.47 & 6.66 & 18.65 & 22.56 & 2.68 \\
\hline & $\mathrm{S}_{3}$ & 13.63 & 6.85 & 6.78 & 19.10 & 20.35 & 2.07 \\
\hline & $\mathrm{S}_{4}$ & 14.82 & 7.99 & 6.83 & 20.80 & 19.86 & 1.79 \\
\hline & $\mathrm{S}_{5}$ & 16.46 & 8.60 & 7.86 & 21.15 & 18.15 & 1.18 \\
\hline \multirow{5}{*}{$\begin{array}{l}\text { BAU Aam-6 } \\
\left(\mathrm{V}_{2}\right)\end{array}$} & $\mathrm{S}_{1}$ & 7.56 & 4.36 & 3.20 & 13.35 & 72.50 & 3.32 \\
\hline & $\mathrm{S}_{2}$ & 12.40 & 5.10 & 7.30 & 18.30 & 62.44 & 1.83 \\
\hline & $\mathrm{S}_{3}$ & 14.83 & 7.44 & 7.39 & 19.35 & 60.31 & 1.81 \\
\hline & $\mathrm{S}_{4}$ & 15.81 & 8.41 & 7.40 & 21.40 & 52.01 & 1.22 \\
\hline & $\mathrm{S}_{5}$ & 18.50 & 9.49 & 9.01 & 22.95 & 22.30 & 1.20 \\
\hline \multirow{5}{*}{$\begin{array}{l}\text { BAU Aam-7 } \\
\left(\mathrm{V}_{3}\right)\end{array}$} & $\mathrm{S}_{1}$ & 6.66 & 3.93 & 2.73 & 13.35 & 57.15 & 3.35 \\
\hline & $\mathrm{S}_{2}$ & 10.70 & 4.34 & 6.36 & 17.50 & 43.36 & 2.03 \\
\hline & $\mathrm{S}_{3}$ & 13.48 & 6.70 & 6.78 & 18.90 & 41.11 & 1.66 \\
\hline & $\mathrm{S}_{4}$ & 14.72 & 7.85 & 6.87 & 20.70 & 38.50 & 1.26 \\
\hline & $\mathrm{S}_{5}$ & 16.09 & 8.62 & 7.47 & 21.60 & 19.64 & 1.20 \\
\hline \multirow{5}{*}{$\begin{array}{l}\text { BAU Aam-8 } \\
\left(\mathrm{V}_{4}\right)\end{array}$} & $\mathrm{S}_{1}$ & 6.86 & 3.97 & 2.89 & 12.90 & 54.35 & 4.04 \\
\hline & $\mathrm{S}_{2}$ & 11.56 & 5.19 & 6.37 & 19.85 & 50.12 & 3.01 \\
\hline & $\mathrm{S}_{3}$ & 14.90 & 7.48 & 7.42 & 20.85 & 46.47 & 2.08 \\
\hline & $\mathrm{S}_{4}$ & 16.00 & 8.51 & 7.49 & 22.25 & 36.20 & 1.48 \\
\hline & $\mathrm{S}_{5}$ & 17.52 & 9.13 & 8.39 & 22.80 & 18.98 & 1.31 \\
\hline $\mathrm{LSD}_{0.05}$ & & 0.575 & 0.105 & 0.361 & 0.538 & 1.580 & 0.118 \\
\hline $\mathrm{LSD}_{0.01}$ & & 0.775 & 0.142 & 0.487 & 0.724 & 2.128 & 0.159 \\
\hline $\begin{array}{l}\text { Level of } \\
\text { significance }\end{array}$ & & $* *$ & $* *$ & $* *$ & $* *$ & $* *$ & $* *$ \\
\hline
\end{tabular}

\section{Acknowledgement}

This study was financially supported by Ministry of Education, Govt. of the People's Republic of Bangladesh under Grants for Advanced Research in Sciences (Project No: 2014/26/BAU).

\section{References}

Absar, N.; Karim, M. R. and Amin, M. A. 1993. A comparative study on the changes in the physicochemical composition of ten varieties of mango in Bangladesh at different stages of maturity. Bangladesh Journal of Agricultural Research, 18(2): 201-208. 
AOAC. 2000. Official Method of Analysis. Association of Official Analytical Chemists.17th edn. Arlington Virginia.

BBS. 2012. Statistical Pocket Book of Bangladesh, Bangladesh Bureau of Statistics, Planning Division, Ministry of Planning, Government of the People's Republic of Bangladesh.

Crisosto, C. H.; Crisosto, G. M. and Metheney, P. 2003. Consumer acceptance of "Brooks" and "Bing" Cherries are mainly dependent on fruit SSC and visual skim color, 28: 159-167.

Firmin, A. 1997. Physico-chemical changes in papaya during storage. Tropical Science, 37: 49-51.

Haque, M. A. 1985. Ripening time and weight loss during ripening of "Amritasagar" banana. Bangladesh Journal of Agricultural Research, 10: 156-158.

Hossain, A. K. M. A. and Ahmed, A. 1994. A monograph on mango varieties in Bangladesh. HRC-BARI and FAO/UNDP Mango Improvement Project. pp. 3.

Hossian, A. K. M. A. 1989a. A field guide on insect Pests and Diseases of Mango in Bangladesh and their Control. Horticulture Division, BARI, Gazipur. pp. 43.

Kays, S. J. 1991. Postharvest Physiology of Perishable Plant Products Vas Nostrand Rein Hold Book, AVI Publishing Company. pp. 149-316.
Kittur, F. S.; Saroja, N.; Habibunnisa, M. and Tharanathan, R. N. 2001. Polysaccharide-based composite coating formulations for shelf-life extension of fresh banana and mango. European Food Research and Technology, 213: 306-311.

Naher, N. 2000. Physico-chemical changes of papaya under different storage conditions, MS thesis, Department of Horticulture, BAU, Mymensingh. pp. 60-93.

Pramanik, M. A. J. 1995. Effects of Different Post Harvest treatments on physico-chemical changes during storage and shelf life of mango. M.S. Thesis, Department of Horticulture, BAU, Mymensingh.

Ranganna, S. 1979. Manual of Analysis of Fruit and Vegetable Products. Tata McGraw-Hill Publishing Company Limited, New Delhi. pp. 634.

Saha, N. N.; Bhuyan, M. A. J. and Islam, M. A. 1995. Variability in early and mid-seasons mango varieties grown in Bangladesh. Bangladesh Journal of Agricultural Science, 5(2): 135-138.

Shafique, M. Z. 2006. Studies on the Physiological and Biochemical Composition of Different Mango Cultivars at Various Maturity Levels. Bangladesh Journal of Science and Industrial Research, 41: 101-108.

Shahjahan, M.; Sheel, S.; Zaman, M. A. and Shakur, M. A. 1994. Optimization of harvesting maturities for major mango cultivars in Bangladesh. Bangladesh Journal of Scientific Research, 12(2): 209-215. 